\title{
The Brazilian consumer's understanding and perceptions of organic vegetables: a Focus Group approach
}

\author{
Entendimento e percepções do consumidor brasileiro em relação \\ a vegetais orgânicos: uma abordagem utilizando Focus Group
}

\section{Luciana Lopes Souza SOARES ${ }^{1 \star}$, Rosires DELIZA², Silvana Pedroso OLIVEIRA²}

\begin{abstract}
Focus Group is a tool which generates, through interview sessions with a small number of participants, preliminary data to be used in subsequent quantitative stages. Many consumer studies use qualitative research with the aim of obtaining information and opinions on a specific product or situation. The objective of the present study was to obtain knowledge on the opinion, understanding and perception of the Brazilian consumer with respect to vegetables, focusing on organic products, using Focus Group Sessions. Four Focus Group Sessions were held with men and women in different environments, following a previously elaborated interview guide. In this study, it was observed that the consumers demonstrated being interested in having a healthy diet, based on fruit, vegetables and natural products. However, only a few declared consuming organic foods. Some participants did not know what the term organic meant, and most of them think that organic products are still very expensive, are not easily available in the supermarkets, do not have a good appearance, mainly in terms of size and packaging, and their certification is not always trustworthy. Almost all participants stated that they read package labels and among the items most observed were best-before date, nutritional information, production system and price. This study has identified important vegetable attributes perceived by the consumer, favouring the planning of a subsequent quantitative research. The results suggest that more information on the benefits of organic agriculture has to be passed on to consumers in order to contribute to a higher consumption of such products.

Keywords: qualitative research; organic vegetables; Focus Group sessions; consumers.
\end{abstract}

\section{Resumo}

Focus Group é uma ferramenta que permite obter, através de sessões de entrevistas com reduzido número de participantes, informação e opinião sobre algum produto ou serviço específico, as quais podem ser utilizadas em etapas quantitativas subseqüentes. O presente estudo objetivou conhecer a opinião, entendimento e percepção do consumidor sobre vegetais, com ênfase nos produtos orgânicos, usando sessões de Focus Groups. Quatro sessões foram conduzidas com homens e mulheres em diferentes ambientes, seguindo roteiro de entrevista previamente elaborado. Neste estudo foi observado que os participantes se demonstraram interessados em ter uma alimentação saudável, baseada em frutas, verduras e produtos naturais. Entretanto, poucos consumidores declararam consumir produtos orgânicos. Vários indivíduos não sabiam o significado do termo orgânico e a maioria deles considerou produto orgânico muito caro, com baixa disponibilidade nos supermercados, aparência não muito boa principalmente em termos de tamanho e embalagem e, além disso, considerou também a certificação não muito confiável. A quase totalidade dos indivíduos afirmou que lêem rótulos e embalagens, com atenção para prazo de validade, informação nutricional, tipo de produção e preço. Este estudo identificou importantes atributos dos vegetais percebidos pelo consumidor, favorecendo o planejamento de subseqüente estudo quantitativo. Os resultados sugerem que mais informação sobre os benefícios da cultura orgânica seja passada para os consumidores visando contribuir para o aumento no consumo de produtos advindos de tal cultura.

Palavras-chave: pesquisa qualitativa; vegetais orgânicos; sessões de Focus Group; consumidor.

\section{Introduction}

The need of knowing the reason why an individual purchases a specific product or service, and which factors are important and decisive in his/her purchase intention arises in different market segments. A simple way of beginning this research is by using qualitative instruments which reveal consensus among consumers, developing and improving new ideas, and discovering what actually matters in the moment of the purchase act. Different studies tend to use qualitative research isolated or combined with quantitative methods. The qualita- tive research methods are not planned to collect quantified data. Through their use, what is of interest is not to know how many people will respond in a specific way, or how many will have the same opinion. What is searched by these methods is knowledge on the reason why a consumer might purchase or answer in a specific way. Qualitative research permits a preview of the attitude, opinion, perception, behaviour and consumer habits (HASHIM; RESURRECCION; McWATTERS, 1996). One of the qualitative research methods most used is Focus Group

Recebido para publicação em 6/3/2007

Aceito para publicação em 6/12/2007 (002314)

${ }^{1}$ Departamento de Tecnologia de Alimentos, Universidade Federal Rural do Rio de Janeiro - UFRRJ, BR-465, Km 7, CEP 23890-000, Seropédica - RJ, Brasil,

E-mail:lulopes01@gmail.com

2 Embrapa Agroindústria de Alimentos, Av. das Américas, 29501, CEP 23020-470, Rio de Janeiro - RJ, Brasil

${ }^{*}$ A quem a correspondência deve ser enviada 
(CALDER, 1977; CASEY; KRUEGER, 1994), based on group dynamics, where participants debate over previously elaborated themes following a planned interview guide.

Focus Group is defined as an exercise in group dynamics, where the leading of the group and the interpretation of the results obtained must be understood inside the context of the interaction of the participants (STEWART; SHAMDASANI, 1990). As it is a subjective technique, Focus Group is considered a preliminary research, which must be followed by quantitative researches (CALDER, 1977). This method may be used at any moment of the research program, but it is particularly useful for exploratory research where little is known about the phenomenon of interest or for testing hypotheses (STEWART; SHAMDASANI, 1990). The main advantage of Focus Group is that it allows much more freedom of expression by the participants than other forms of inquiries. In this method, the participants choose the way in which they will answer, allowing interaction, debate, and change of opinion during the discussion with the other participants, adding complexity to the qualitative information (DRANSFIELD et al., 2004). This type of information tends to be difficult to analyse as it is necessary to find its patterns by means of the identification of the opinions, ideas or feelings repeated by participants. Due to this difficulty, Dransfield et al. (2004) investigated the worth of the total objective lexical analysis in the interpretation of Focus Group interviews.

Guerrero et al. (2000), in a preliminary stage of a study on the influence of different types of stores on consumer food choice, carried out two Focus Group sessions with selected consumers and professionals involved in factory and store activities. Deliza, Rosenthal and Silva (2003) used Focus Group to investigate the impact of information on the use of high pressure technology, an unconventional technology, in the production of fruit juice, on consumer product perception. The authors stated that the Focus Group interviews were a useful tool to evaluate the factors which affected the consumer's attitude towards fruit juice, revealing the importance of information on the technology used on the perception of pineapple juice (the fruit juice used in the study). A similar study was carried out by Deliza; MacFie and Hedderley (1999) with British consumers.

Sessions of Focus Group were held in the southern part of the Netherlands to identify the effects of different types of beliefs in the consumption of fruit and vegetables among adult Dutch (BRUG et al., 1995). In another study, Dantas et al. (2004) used Focus Group interviews to investigate the impact of packaging of minimally processed products on the attitude, opinion, thoughts and conceptions of the consumer, specifically regarding minimally processed green cabbage. Results showed that price, package colour, type and amount of information were important aspects that influenced perception and purchase intention of the product.

As the certified organic food segment is the fastest-growing in the food market (LOCKIE et al., 2004), presenting an average growth that ranges from 20 to $30 \%$ per year (MERCADO, 2004), many studies have been developed focusing the evaluation of consumer perception of this type of food. Market research has shown that, in what concerns organic foods, consumers perceive them as being less harmful to the environment, and as foods with less chemical contamination. Nonetheless, consumer reactions to the quality of organic foods are not well established (BRENNAN; KURI, 2002). In Australia, 13 Focus Group interviews were used as a first stage of a study which aimed at investigating the behavioural, attitudinal and motivational factors, which all together influenced the increase of organic food consumption. Being perceived as "natural" was the main determinant of the consumption of certified organic foods (LOCKIE et al., 2004). Eight sessions of Focus Group in the United Kingdom and five in other countries of the European Union were held in order to obtain more knowledge on organic foods and the consumer perception of these foods through a cross-country study. The conclusion drawn was that there is lack of knowledge and confusion among European consumers in relation to the term organic (AARSET et al., 2004). Thus, the motivations towards consumption varied with the country, the culture and the products. Nevertheless, observing countries such as Germany, England, Australia, the United States, France and Denmark, it is possible to notice that there was a tendency of the organic consumer to privilege firstly the aspects related to health and its connection to foods, secondly the environment, and finally the taste of organic foods (AARSET et al., 2004).

Few Brazilian scientific studies have investigated consumer perception towards organic foods. Farina (2002) investigated consumer perception of organic chicken in an open market in São Paulo - SP. It was observed that the organic consumer was less sensitive to price, and more aware of the quality, not only considering food safety, but also the impact of production on the environment and on society. Archanjo et al. (2001), in a study on organic foods in Curitiba - PR, reported that organic consumers believe they are investing in their health, because for them, consuming organic food is a way of preventing diseases. The profile of the organic consumer was discussed in relation to the strategies employed by supermarkets in a study carried out by Guivant (2003). One of the main arguments of this article was that the growing consumption of organics at the supermarket level is part of a broader demand for healthy food, which is in turn part of a lifestyle characterized as 'ego-trip', as opposed to one that is more ecologically responsible, i.e., 'the ecologicaltrip' style of life.

The present study aimed at investigating, through Focus Group sessions, the Brazilian consumer's perception and understanding towards vegetables commercialised in supermarkets, focusing on organic products. The beliefs and values which influence the consumption of organic foods were also investigated.

\section{Materials and methods}

\subsection{Participants and sessions}

Four Focus Group sessions were carried out with a total of 33 participants. The habit of going shopping at the supermarket and of consuming vegetables was the criteria required for the recruitment of the participants. 
The sessions started with everybody introducing themselves and the moderator explaining the objective of the task. Participants read and signed an Explanation and Consent Form, which stated that any information collected would be kept strictly confidential and that their names would not appear in any analyses or published reports. They also were told that they could withdraw from the study at any time without giving explanations. All participants volunteered for the study and did not receive any monetary incentive for their participation. They sat on chairs with individual tables, arranged in a rectangular form in order to favour interaction, visual contact and harmony in the discussion. Each session lasted from 60 to 90 minutes. It was made clear to participants that there would not be correct or wrong answers to the questions, and that they should express their opinions in a sincere way, even if there were disagreements among them.

The first Focus Group session was formed by seven women, most of whom had children and worked at Embrapa Food Technology in the city of Rio de Janeiro, Brazil. This homogenous characteristic of the group is based on the fact that women might consume more organic products than men, as it was demonstrated in a study undertaken by Davies, Titterington and Cochrane (1995). In this study, the authors reported that women who had children presented a tendency to increase the consumption of organic foods. The second group was composed by ten men, who also worked at Embrapa Food Technology, being $50 \%$ married with children and $50 \%$ bachelors. The fact of only having men in the group prevented them from being shy when talking about food in the presence of women, who generally are more familiar with aspects regarding the purchase of foods and choice criteria. Besides, it allowed a more homogenous session, which is a characteristic required when using the Focus Group methodology. The third session was held with eight residents of a middle class residential area in the city of Rio de Janeiro, being the group formed by three men and five women. Finally, the fourth session was held at the City Hall of Resende, a town located in the southern part of the state of Rio de Janeiro, with the participation of civil and hired servants. This session was formed by four men and four women, of which $50 \%$ had children in the household and had a college education level.

\subsection{Conduction of the Focus Group sessions}

The Focus Group sessions followed a planned interview guide with questions previously prepared by a moderator for the conduction of the sessions (Chart 1). The moderator, besides being the person responsible for conducting the sessions, must have characteristics such as: understanding the nature of the research problem; being familiar with recent information on the topic or object of discussion; deciding on the strategy and sequence of the questions which will facilitate the discussion; and knowing how to analyse and interpret the results (STEWART; SHAMDASANI, 1990).

The questions intended to provoke discussion on the following topics: food consumption; aspects related to the food from the consumer's perspective; consumption of organic foods; factors which might contribute to the consumption of organic foods and those that might make this consumption difficult.
Chart 1. Discussion guideline for the Focus Group sessions on organic vegetables.

General questions: as a way to get started.
What is a healthy food to you?
Do the different means of communication interfere with people's
food habits? How?
What do you think of the sentence: if something does not have a
good appearance, its taste is not good either.
How do you consider the issue: food appearance and taste versus
knowing it is healthy?
Organic questions: more related to the topic of the study.
What is organic food to you? In your opinion, is there any
difference between organic food and natural food? If there is,
what is it?
Do you consume organic foods? Which ones? Why? Why not?
What would contribute for you to consume more organic
products?
Would you buy organic food even if its price is higher than
conventional food? How much more would you for pay for
organics?
Question focusing on food packaging: to investigate the effect of the
package on consumer food perception.
Do you read food labels? What do you pay attention to on them?

The elaboration of the interview guide was based on a previous review of the scientific literature and on the main objective of the present study. The first questions of the Focus Group sessions generally have the function of warming up the discussion among participants, and the central and last questions are the ones most concerned with the desired information. Chart 1 shows the interview guide for the experiment.

After the end of each session, participants answered a questionnaire on demographics and fruit and vegetable consumption.

\subsection{Data treatment}

During the first two sessions, research assistants registered the opinions and impressions of the participants while they were answering the questions and expressing their opinions. The third and fourth sessions were tape recorded and the relevant points were registered by a research assistant. The Focus Group sessions were then transcribed. According to Stewart and Shandasani (1990), for each exploratory research, which is the case of the Focus Group used, a simple descriptive narrative is appropriate enough for the analysis of the results. No statistical analysis was carried out due to the qualitative nature of Focus Group.

\section{Results and discussion}

Table 1 shows the description of the participants of the four Focus Group sessions, obtained through a questionnaire answered at the end of each session.

The majority of participants were between 26 and 45 years old and there was a balance in what concerned the number of men and women. Seventy six per cent had a College education level. The family income was predominantly more than five Brazilian minimal wages per month. 
Table 1. Description of the participants of the Focus Group sessions on organic vegetables.

\begin{tabular}{|c|c|c|c|c|}
\hline \multirow{2}{*}{$\begin{array}{c}\text { Characteristics and } \\
\text { description of participants }\end{array}$} & \multicolumn{4}{|c|}{ Frequency $(\%)$} \\
\hline & $\begin{array}{c}\text { Session } 1 \\
(\mathrm{n}=7)\end{array}$ & $\begin{array}{l}\text { Session } 2 \\
(\mathrm{n}=10)\end{array}$ & $\begin{array}{c}\text { Session } 3 \\
(\mathrm{n}=8)\end{array}$ & $\begin{array}{c}\text { Session } 4 \\
(\mathrm{n}=8)\end{array}$ \\
\hline \multicolumn{5}{|l|}{ Gender } \\
\hline Male & 0 & 100 & 38 & 50 \\
\hline Female & 100 & 0 & 62 & 50 \\
\hline \multicolumn{5}{|l|}{ Age (years) } \\
\hline $18-25$ & 0 & 0 & 0 & 25 \\
\hline $26-35$ & 71 & 40 & 12 & 13 \\
\hline $36-45$ & 0 & 30 & 38 & 50 \\
\hline $46-55$ & 29 & 30 & 25 & 12 \\
\hline $56-65$ & 0 & 0 & 25 & 0 \\
\hline$\geq 66$ & 0 & 0 & 0 & 0 \\
\hline \multicolumn{5}{|l|}{ Education level } \\
\hline None & 0 & 0 & 0 & 0 \\
\hline Basic & 0 & 0 & 0 & 0 \\
\hline Incomplete high school & 0 & 0 & 13 & 0 \\
\hline High school & 0 & 0 & 0 & 25 \\
\hline Incomplete college level & 0 & 20 & 13 & 25 \\
\hline Complete college level & 29 & 30 & 37 & 37 \\
\hline Post-graduation & 71 & 50 & 37 & 13 \\
\hline \multicolumn{5}{|l|}{$\begin{array}{l}\text { Monthly family income } \\
\left.\text { (minimal wages }{ }^{*}\right)\end{array}$} \\
\hline $1-5$ & 0 & 0 & 0 & 0 \\
\hline $5-10$ & 42 & 60 & 0 & 37 \\
\hline $10-20$ & 29 & 40 & 50 & 50 \\
\hline $20-30$ & 0 & 0 & 25 & 13 \\
\hline$>30$ & 29 & 0 & 25 & 0 \\
\hline
\end{tabular}

Figures $1 \mathrm{a}$ and $1 \mathrm{~b}$ illustrate some of the answers of the questionnaire. The frequency of consumption of fruit and vegetable was high among participants, as can be seen in Figure 1a. Consumers declared eating fruit and vegetable "frequently" (at least four times a week) or "daily". Figure $1 \mathrm{~b}$ presents the items considered most important to consumers when observing food labels.

The Focus Group sessions revealed that the participants were interested in talking about subjects related to health and food consumption, natural products, factors which might interfere with the purchase of foods, as all these subjects involve issues which are experienced daily by everybody, regardless of the degree of information and knowledge on the concepts related to food. Through the answers of the questionnaire applied at the end of each session, it was confirmed that all participants consumed fruit and vegetable. Participants mentioned they had notions about what a healthy diet is. It was said by several consumers of the four sessions that they believed they had a balanced diet, with a variety of foods which may be taken advantage of by the body. They also commented that a healthy diet must take into account each individual's needs in terms of quality and quantity. When the moderator asked about the meaning of a healthy diet, many mentioned the consumption of fruit and vegetable.
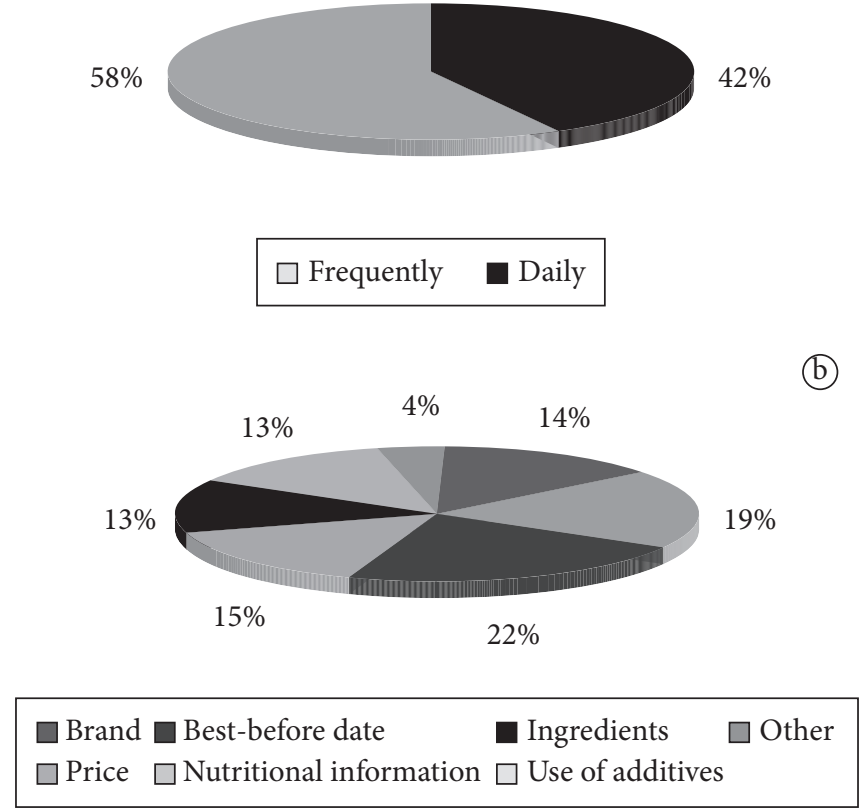

Figure 1. a) Frequency of fruit and vegetable consumption; and b) Items on labels considered most important by consumers.

Regarding the influence of the media on consumers' food habits, the great majority of participants agreed that the different communication media have strong interference in food choice and consumption. The media, from the participants' viewpoint, "sets the rules", even with respect to food, and if it were well utilised, it could provide guidance on a healthy diet.

Through the answers, it was possible to notice that the appearance of foods greatly determines their intake. Many respondents admitted they aim at consuming foods which have the best appearance. However, if they already know the taste of some specific food, they eat it, even if its appearance is bad. According to them, what makes the appearance to be considered good or bad depends on the context and the culture in which the individuals are inserted. Besides, the appearance also depends on the way foods are prepared. As it was cited: "At home, one can not make beautiful French fries and an ugly lettuce salad", in order to demystify the idea that only what is harmful to health is what has a beautiful appearance. The issue of appearance was approached in the interview guide, considering that several studies reported an appearance difference between organic and conventional vegetables (JOHANSSON et al., 1999; MODESTA et al., 2004). Furthermore, according to Kays (1999), appearance tends to be one of the first criteria in the purchase decision process. In Chart 2, there is a summary of the responses of the participants in each session.

When asked about the difference between natural and organic food, some participants answered that natural is the food which is not industrialised, without additives, whereas organic is the food which has no chemical pesticide. Nonetheless, some consumers were not able to tell if there was a difference or not. 
Similar results were found by Dantas et al. (2004). The authors reported that consumers did not understand the meaning of organic and stated that there was no advantage in declaring on the label a product characteristic which was not understandable by consumers. In another work carried out by Abadio (2003), it has been suggested that informing consumers about the meaning of an organic product would be valuable for the product, contributing to a higher quality perception.

In the second session, formed only by men, the majority declared not to consume organic food. Many reported they did not eat it because they did not believe that such products, when sold in supermarkets, were actually derived from organic production systems. This observation may imply that the certification process has to be improved regarding its communication to consumers.

Another factor which was mentioned, also determinant of the non-consumption of organic foods, was the price, which, according to them, normally is higher than that of conventional food, giving the impression, to some of participants, that the cost-benefit relationship is not advantageous.

Chart 2. Main comments made by participants during the four Focus Group sessions on organic vegetables.

Session 1

Natural food has no preservatives and colorings.

Organic food has no chemical pesticides.

Organic food is expensive and does not have a good appearance.

There is a lack of advertising and information necessary to increase the consumption of organic foods.

The majority would not pay more for organic food.

Important items on the package: label information, certification and biodegradable package.

Session 2

Organic is a brand which confuses people.

Organic production is a rescue of old means of production.

The majority does not consume organic foods.

To increase organic consumption: lower prices, more information, more confidence on the product origin, and greater availability in the market.

Relevant items on the package: price, best-before date and nutritional information.

Session 3

The majority did not know the meaning of organic.

Consider organic food as inaccessible and elitist.

To increase organic food consumption, more information is needed.

One participant said he had never seen organic food.

Most observed items on the package: best-before date, food appearance and price.

Session 4

The majority did not know what organic food is.

Price is a determinant factor in food choice and purchase.

To start consuming organic food, more information and confidence in the product is necessary.

Important items on the label: price, best-before date and nutritional information.
According to the general viewpoint of the participants, the factors which would contribute to increase organic food consumption would be price reduction; information on benefits to health and to the environment, since many people do not know organic foods; the knowledge about the origin of the product, in order to increase consumer confidence; and the availability in the market, as organic foods are not easily found. Similar findings were presented by Siderer, Maquet and Anklam (2005), with emphasis on the identification of specific health effects, showing that organically produced food is generally healthier than non-organic. When asked about how much more they would pay for organic food, having in mind the benefits they bring to health, most of the participants answered they would not pay more than $30 \%$ of the value of conventional food. Such an answer opposes the Brazilian reality, as organic vegetables sold in supermarkets, for example, are around $40 \%$ to $100 \%$ more expensive, when compared to conventional vegetables (KISS, 2004).

Although food packaging was not a key point in this study, this subject was introduced by participants of the first Focus Group session. The PVC (polyvinyl chloride) films were considered harmful to air circulation and, consequently, to the appearance and to the freshness of organic foods. Participants of this session also commented they do not like buying foods packaged in polystyrene trays in supermarkets (like the organic vegetables) because they are harmful to the environment. Darolt (2003) had already made a similar remark when he reported that this type of package generates a contradiction when one deals with a kind of food which is produced in an "ecologically correct" way. And in the fourth session, some consumers did not show themselves as being favourable to packaged vegetables, as they think the producer uses this procedure for "disguising" something that is bad in the food so that he will be able to sell it.

At the end of the discussion, it was asked to participants which information they considered to be the most important in the food label/package. Figure 2 illustrates consumers' answers on the main food characteristics and the items most searched by them, when looking at the label/package in the purchase act.

The items most cited were appearance, best-before date, price and nutritional information. The appearance of the food was reported as being something which was the most observed when looking at the label/package. The kind of package seemed to be a relevant issue when buying fruit and vegetable, as could be observed in Session 1, where biodegradable packaging was declared as preferred (Chart 2).

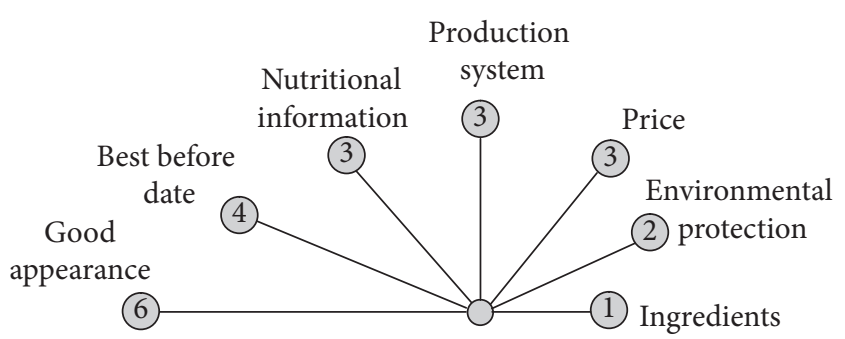

Figure 2. Number of times, expressed inside the grey area, showing the main food characteristics and the items most searched by consumers when looking at the label/package. 


\section{Conclusion}

The information raised by the four Focus Group sessions suggests that there is a growing consumer interest in having a healthy diet, which will provide welfare and safety to them and their families. Organic foods, especially vegetables, correspond to what participants consider as healthy. In order to promote an increase in the Brazilian organic market, the results suggest that more information on the benefits of organic agriculture has to be passed on to consumers. It was implied, from the sessions, that participants would consume more organic products if they were sure that products labelled as such were really from an organic production system. This is an important result which has to be considered by organic food producers and certification institutions. As a starting point for a broader study, this research identified important attributes which can be used in a further quantitative study aiming at evaluating the perception of organic vegetables by the consumer. Such attributes were information, price, appearance, and packaging. The first two attributes seemed to be determinant factors for the consumption of organic products by participants in general, despite the differences in education level, family income and professional activity among the groups.

\section{Acknowledgements}

The authors wish to express their gratitude to EMBRAPA's employees, the residents of Condominium Rio 2 in Rio de Janeiro - RJ, and to the civil servants of the City Hall of Resende - RJ, who participated in this study as volunteers. They also thank CAPES (Coordination for the Improvement of Higher Education Personnel) and EMBRAPA (Brazilian Agricultural Research Corporation) for the financial support.

\section{References}

AARSET, B. et al. The European Consumers' Understanding and Perceptions of the "Organic" Food Regime: the Case of Acquaculture. British Food Journal, Bradford, v. 106, n. 2, p. 93-105, 2004.

ABADIO, F. D. B. Efeitos de diferentes fatores de informação da embalagem de suco de abacaxi (Ananás comosus L. Merr) no comportamento do consumidor. 2003. 79 f. Dissertação (Mestrado em Ciência e Tecnologia de Alimentos) - Universidade Federal Rural do Rio de Janeiro.

ARCHANJO, L. R; BRITO, K. F. W; SAUERBECK, S. Alimentos Orgânicos em Curitiba: Consumo e Significado. Cadernos de Debate, Campinas, v. 8, p. 1-6, 2001.

BRENNAN, C. S; KURI, V. Relationship between Sensory Attributes, Hidden Attributes and Price in Influencing Consumer Perception of Organic Foods. In: POWELL et al. UK Organic Research 2002: Proceedings of the COR Conference, Aberystwyth, 2002, p. 65-68.

BRUG, J. et al. Psychosocial Determinants of Fruit and Vegetable Consumption among Adults: Results of Focus Group Interviews. Food Quality and Preference, Oxford, v. 6, n. 2, p. 99-107, 1995.

CASEY, M. A; KRUEGER, R. A. Focus Group Interviewing. In: MacFIE, H. J. H.; THOMSON, D. M. H. Measurement of Food Preferences. London: Ed. Blackie Academic \& Professional, 1994. p. 77-97.
CALDER, B. J. Focus Group and the Nature of Qualitative Marketing Research. Journal of Marketing Research, Chicago, v. 14, p. 353-364, 1977.

DANTAS, M. I. S et al. The effect of packaging on the perception of minimally processed products. Journal of International Food \& Agribusiness Marketing, New York, v. 16, n. 2, p. 71-83, 2004.

DAROLT, M. R. Why organic foods are more expensive? [Por que os alimentos orgânicos são mais caros?]. Disponível em: <http:// www.planetaorganico.com.br/trabdarolt1.htm>. Acesso em: 9 may 2003.

DAVIES, A.; TITTERINGTON, A. J.; COCHRANE, C. Who buys organic food? A profile of the purchasers of organic food in Northern Ireland. British Food Journal, Bradford, v. 97, n.10, p. 17-23, 1995.

DELIZA, R.; MacFIE, H. J. H.; HEDDERLEY, D. An Investigation Of The Package Features Affecting Consumer Perception Of Fruit Juice Using Repertory Grid And Focus Group Methods. Brazilian J. Food Technology, Campinas, v. 2, n. 1/2, p. 63-71, 1999.

DELIZA, R.; ROSENTHAL, A.; SILVA, A. L. S. Consumer attitude towards information on non conventional technology. Trends in Food Science \& Technology, London, v. 14, n. 1/2, 14, p. 43-49, 2003.

DRANSFIELD, E. et al. The application of a text clustering statistical analysis to aid the interpretation of focus group interviews. Food Quality and Preference, Oxford, v. 15, n. 5, p. 477-488, 2004.

FARINA, E. M. Q. et al. Estudo do sistema agroindustrial de produtos orgânicos no estado de São Paulo. São Paulo: FIPE/SEBRAE/ PENSA, fev. 2002. 293 p.

GUERRERO, L. et al. Consumer attitude towards store brands. Food Quality and Preference, Oxford, v. 11, n. 5, p. 387-395, 2000.

GUIVANT, J. S. Os supermercados na oferta de alimentos orgânicos: apelando ao estilo de vida ego-trip. Ambiente e Sociedade, Campinas, Unicamp, v. 6, n. 2, p. 63-81, 2003.

HASHIM, I. B.; RESURRECCION, A. V. A; MCWATTERS, K. H. Consumer Attitudes towards Irradiated Poultry. Food Technology, Chicago, v. 50, n. 3, p. 77-80, 1996.

JOHANSSON, L. et al. Preference for Tomatoes, Affected by Sensory Attributes and Information about Growth Conditions. Food Quality and Preference, Oxford, v. 10, n. 4-5, p. 289-298, 1999.

KISS, J. Terra em transe. Globo Rural. Editora Globo, n. 223, p. 34-42, 2004.

LOCKIE, S. et al. Choosing organics: a path analysis of factors underlying the selection of organic food among Australian consumers. Appetite, London, v. 43, n. 2, p. 135-146, 2004.

MERCADO de Orgânicos cresce até 30\% no País. Gazeta Mercantil, São Paulo, 28 Sept. 2004.

MODESTA, R. C. D. et al. Sensory quality evaluation of conventional and organic lettuce. [Avaliação da Qualidade Sensorial de Alface Crespa Convencional e Orgânica]. In: $2^{\circ}$ Congresso de Pesquisa Científica da Universidade Federal Rural do Rio de Janeiro, 2004, Seropédica - RJ.

SIDERER, Y.; MAQUET, A.; ANKLAM, E. Need for research to support consumer confidence in the growing organic food market. Trends in Food Science \& Technology, Cambridge, v. 16, n. 8, p. 332-343, 2005.

STEWART, D. W.; SHAMDASANI, P. N. Focus Groups: Theory and Practice. London: SAGE, v. 20, 1990. 153 p. 